\title{
Rat Liver Sinusoidal Endothelial Cells (LSECs) express functional Low Density Lipoprotein Receptor-Related Protein-1 (LRP-1)
}

Cristina Ionica $Ø \mathrm{ie}^{1}$, Rupa Shree Appa ${ }^{2}$, Ida Hilden ${ }^{2}$, Helle Heibroch Petersen ${ }^{2}$, Albrecht Gruhler $^{2}$, Bård Smedsrød ${ }^{3}$, John-Bjarne Hansen $^{1}$

From the ${ }^{1}$ Center for Atherothrombotic Research in Troms $\varnothing$ (CART), Department of Medicine, Institute of Clinical Medicine, University of Troms $\varnothing$, Troms $\varnothing$, Norway; the

${ }^{2}$ Biopharmaceutical Research Unit, Novo Nordisk, Måløv, Denmark; and the ${ }^{3}$ Vascular Biology Research Group, Institute of Medical Biology, University of Troms $\varnothing$, Troms $\varnothing$, Norway

Corresponding author: Cristina Ionica Øie, Center for Atherothrombotic Research in Troms $\emptyset$, Institute of Clinical Medicine, University of Troms $\varnothing$, N-9037 Troms $\varnothing$, Norway. Telephone: +4777644686 (cell +4791682978); Fax: +4777645400; e-mail: cristina.ionica.oie@uit.no

\section{Word count: 5355}

\section{Number of figures and tables: 6 / 0}

\begin{abstract}
Abbreviations: RAP, receptor associated protein; $\alpha_{2} \mathrm{M}^{*}$, trypsin-activated $\alpha_{2}-$ Macroglobulin; PC, parenchymal cell; FSA, formaldehyde-treated bovine serum albumin; $\alpha$-coll, collagen $\alpha$-chains; HA, hyaluronan; RT, room temperature; KC, Kupffer cell Financial disclosure: The present study was supported by an independent grant from Pfizer AS (JBH); Troms $\varnothing$ Research Foundation (BS), and Medical Faculty, University of Tromsø, Norway (JBH, BS)
\end{abstract}




\begin{abstract}
Background and Aims: The low density lipoprotein receptor-related protein-1 (LRP-1) is a large, multifunctional endocytic receptor from the LDL receptor family, highly expressed in liver parenchymal cells (PCs), neurons, activated astrocytes and fibroblasts. The aim of the study was to investigate if liver sinusoidal endothelial cells (LSECs), highly specialized scavenger cells, express LRP-1. Methods: To address this question, experiments were performed in vivo and in vitro to determine if receptor associated protein (RAP) and trypsin-activated $\alpha_{2}$-macroglobulin $\left(\alpha_{2} \mathrm{M}^{*}\right)$ were endocytosed in LSECs. Results: Both ligands were cleared from the circulation mainly by the liver. Hepatocellular distribution of intravenously administered ligands assessed after magnetic bead cell separation using LSEC- and KC-specific antibodies showed that PCs contained $93 \%$ and $82 \%$ of liver-associated ${ }^{125} \mathrm{I}-\mathrm{RAP}$ and ${ }^{125} \mathrm{I}-\alpha_{2} \mathrm{M}^{*}$, whereas $5 \%$ and $11 \%$ were associated with LSECs. Uptake of RAP and $\alpha_{2} \mathrm{M}^{*}$ in the different liver cell population in vitro was specific and followed by degradation. The uptake of ${ }^{125} \mathrm{I}-\mathrm{RAP}$ was not inhibited by ligands to known endocytosis receptors in LSECs, while uptake of ${ }^{125} \mathrm{I}-\alpha_{2} \mathrm{M}^{*}$ was significantly inhibited by RAP, suggesting the involvement of LRP-1. Immunofluorescence using LRP-1 antibody showed positive staining in LSECs. Ligand blot analyses using total cell proteins and ${ }^{125}$ I-RAP followed by mass spectrometry further confirmed and identified LRP-1 in LSECs. Conclusion: LSECs express functional LRP-1. An important implication of our findings is that LSECs contribute to the rapid removal of blood borne ligands for LRP-1 and may thus play a role in lipid homeostasis.
\end{abstract}

Word count abstract: 241 
Keywords: receptor-mediated endocytosis, blood clearance, RAP, $\alpha_{2}$-macroglobulin, lipid homeostasis. 


\section{Introduction}

The liver represents a major cleaning station of the body, daily eliminating large amounts of circulating macromolecules. Liver sinusoidal endothelial cells (LSECs) are a specialized type of endothelium, lining the liver sinusoids, that use receptor-mediated endocytosis to take up and degrade numerous physiological and non-physiological soluble macromolecules and colloids from the blood [35]. In addition, through their fenestrations, LSECs act as a dynamic filter facilitating the exchange of substrates between blood and hepatocytes [47].

Low density lipoprotein receptor-related protein-1 (LRP-1), a member of the LDL receptor family, is a large, multifunctional endocytic receptor expressed in liver parenchymal cells (PCs), neurons, activated astrocytes and fibroblasts [45]. LRP-1 is synthesized as a single polypeptide chain cleaved in the trans-Golgi to form a heterodimer of two noncovalently bound proteins, a $515 \mathrm{kDa}$ subunit ( $\alpha$-chain) containing its binding domains, and a $85 \mathrm{kDa}$ subunit ( $\beta$-chain) containing the membrane-spanning region and cytoplasmic tail [18]. LRP-1 is known to interact and mediate endocytosis of more than 40 unrelated ligands ranging from proteins involved in lipoprotein metabolism, viruses to protease/protease inhibitor complexes cytokines, and growth factors [19].

LRP-1 and other members of the LDL receptor family associate with a specific chaperone, receptor-associated protein (RAP). RAP binds LRP-1 at multiple sites to block its interaction with ligands during biosynthesis and traffic to the cell surface [4]. Exogenous administration of RAP acts as a receptor antagonist for all ligands of the LDL receptor family, thus rendering RAP a valuable tool to study the LDL receptor gene 
family's biochemistry and to investigate potential specific interaction of ligands with LRP-1 and LRP-1 related proteins in vivo and in vitro [46].

$\alpha_{2}$-Macroglobulin $\left(\alpha_{2} \mathrm{M}\right)$ [1] is a major human blood glycoprotein able to trap and inactivate a large variety of proteinases, and inhibit fibrinolysis by reducing plasminogen to kallikrein [41]. The $\alpha_{2} \mathrm{M}$-proteinase complex, the "activated" $\alpha_{2} \mathrm{M}\left(\alpha_{2} \mathrm{M}^{*}\right)$, becomes a specific ligand for the LRP-1, and is eliminated from the circulation by LRP-mediated endocytosis and subsequently degraded [41]. $\alpha_{2} \mathrm{M}$ was recently found to be a noninvasive serological biomarker that could predict the stage of liver fibrosis [20]

The expression and function of the LRP-1 in liver was so far studied in PCs or PC-like cell lines $[2,6,7,42,43]$. Using RAP and $\alpha_{2} \mathrm{M}^{*}$ as potent ligands for LRP-1, we investigated whether this receptor is also expressed in LSECs. 


\title{
Materials and Methods
}

\begin{abstract}
Animals
Male Sprague-Dawley rats ( 250g) were from Scanbur BK AB (Sollentuna, Sweden). All experimental protocols were approved by the Norwegian Animal Research Authority in accordance with the Norwegian Animal Experimental and Scientific Purposes Act of 1986.
\end{abstract}

\section{Chemicals}

Receptor associated protein (RAP) was expressed and purified from Escherichia coli strain BL21(DE3) (Invitrogen, Taastrup, Denmark) [8](supplementary material). Binding to LRP-1 (BioMac, Leipzig, Germany) was tested by Surface Plasmon Resonance (Biacore 3000 Biosensor instrument, GE Healthcare). $\alpha_{2}$-Macroglobulin $\left(\alpha_{2} \mathrm{M}\right)$ from bovine plasma was from Roche Diagnostics Norge AS (Olso, Norway). Carrier free $\mathrm{Na}^{125}$ I was from Perkin-Elmer Norge AS (Oslo, Norway), and 1,3,4,6-tetrachloro-3 $\alpha, 6 \alpha$ diphenylglycoluril (Iodogen) and tetramethylrhodamine isothiocyanate (TRITC) were from Pierce Chemical Co., (Rockford, Illinois). Collagenase P was from Worthington Biochemical Corporation (Lakewood, New Jersey). RPMI 1640, penicillin and streptomycin were from PAA (Pashing, Austria). Bovine serum albumin (BSA), mannan, trypsin, soybean trypsin inhibitor, CHAPS and Hepes were from Sigma Co (St. Louis, Missouri), protease inhibitor from Roche (Copenhagen, Denmark), SDS-PAGE gels, nitrocellulose filters, Dynabeads M-280 tosylactivated and MultiMark® Multi-Colored Protein Standard were from Invitrogen. PD-10 columns and Percoll were from Amersham Biotech (Uppsala, Sweden). Formaldehyde-treated bovine serum albumin 
(FSA) was prepared as described [31]. High molecular weight hyaluronan (HA) was from Pharmacia (Uppsala, Sweden). Collagen $\alpha$-chains ( $\alpha$-coll) were obtained by incubation at $60^{\circ} \mathrm{C}$ for $60 \mathrm{~min}$ of native triple helical collagen (Vitrogen, Palo Alto, California).

\section{Labeling Procedures}

RAP and $\alpha_{2} \mathrm{M}(50 \mu \mathrm{g})$ in PBS were directly labeled with $\mathrm{Na}^{125}$ I employing Iodogen as oxidizing agent [27]. Specific radioactivities were between $5-8 \times 10^{6} \mathrm{cpm} / \mu \mathrm{g} . \alpha_{2} \mathrm{M}$ trypsin complexes $\left(\alpha_{2} M^{*}\right)$ were prepared as described [16]. Briefly, $\alpha_{2} M$ or ${ }^{125} \mathrm{I}-\alpha_{2} \mathrm{M}$ was incubated with 2 fold molar trypsin for $5 \mathrm{~min}$ at RT, followed by addition of soybean trypsin inhibitor, 5 fold molar more than trypsin. The complex formation was tested by gelatin zymography. FSA in $\mathrm{Na}_{2} \mathrm{CO}_{3}(0.1 \mathrm{M}, \mathrm{pH} 9.5)$ was incubated with TRITC at a ligand/dye weight ratio of $5: 1$, at $4{ }^{\circ} \mathrm{C}$ overnight and then dialyzed against PBS.

\section{Anatomical Distribution}

Anatomical distribution of intravenously (i.v.) administered ${ }^{125}$ I-RAP and ${ }^{125} \mathrm{I}-\alpha_{2} \mathrm{M}^{*}(0.5$ $\mu \mathrm{g})$ were determined as described [38]. Total blood volume was calculated [44].

\section{Hepatocellular Distribution}

Ten min after i.v. administration of $5 \mu \mathrm{g}$ of ${ }^{125} \mathrm{I}-\mathrm{RAP}$ or ${ }^{125} \mathrm{I}-\alpha_{2} \mathrm{M}^{*}$, different liver cells were purified as described bellow. The uptake per cell population in the total liver was calculated based on the rat liver ratio KCs:LSECs:PCs=1:2.5:7.7 [33].

Isolation of PCs, LSECs and KCs 
PCs, LSECs and KCs were prepared by collagenase perfusion of the liver, low speed differential centrifugation and Percoll gradient sedimentation [39], followed by magnetic cell separation (MACS) for isolation of KCs and LSECs [11], using biotin anti-rat CD11b and biotin anti-rat ICAM-1 (Cedarlane ${ }^{\circledR}$, Ontario, Canada) / streptavidin-conjugated magnetic beads, respectively (Miltenyi, Inc.), over two $\mathrm{MS}^{+}$MiniMACS separation columns according to the manufacturer. The purity of the PCs (> 95\%) was easily assessed by inspection in the light microscope, as these cells are much larger in diameter as compared to other liver cells. The purity of LSECs cultures and the degree of LSECs contamination in the KCs cultures was assessed by immunostaing using Stabilin2 antibody [17, 28]. LSEC preparations were between $95-98 \%$ pure. The degree of LSEC contamination in $\mathrm{KCs}$ was less than $10 \%$.

\section{Kinetics and specificity of endocytosis}

Cultures of PCs $\left(0.25 \times 10^{6}\right)$ and LSECs $\left(0.5 \times 10^{6}\right)$ were established on fibronectin coated 24-well plates (Becton Dickinson, Playmount, UK), and KCs $\left(0.35 \times 10^{6}\right)$ on noncoated plastic in 48 -well plates. Endocytosis kinetics of ${ }^{125} \mathrm{I}-\mathrm{RAP}(4.27 \mathrm{ng})$, and ${ }^{125} \mathrm{I}-$ $\alpha_{2} \mathrm{M}^{*}$ (10 ng), were studied at $37^{\circ} \mathrm{C}$ for various time periods. Endocytosis specificity was studied by incubating LSECs for $2 \mathrm{~h}$ at $37^{\circ} \mathrm{C}$ with trace amounts of ${ }^{125} \mathrm{I}$-RAP or ${ }^{125} \mathrm{I}-$ $\alpha_{2} \mathrm{M}^{*}$ alone (control), or with non-labeled (100 $\left.\mu \mathrm{g} / \mathrm{ml}\right) \mathrm{RAP}, \alpha_{2} \mathrm{M}^{*}$, FSA, Mannan, $\alpha$ coll or HA. Degradation was determined in the spent media by measuring the amount of acid soluble radioactivity after addition of TCA and centrifugation. Cell-associated ligand was measured in cells solubilized in 1\% SDS. The amount of the non-specific binding and free ${ }^{125} \mathrm{I}$ in the cell free wells was subtracted. 


\section{Immunofluorescence staining for LRP-1}

LSECs on fibronectin coated coverslips were incubated with TRITC-FSA for $1 \mathrm{~h}$ at $37^{\circ} \mathrm{C}$. Unbound TRITC-FSA was removed by washing and incubation continued for another hour. The cells were fixed for 10 min at RT with 4\% paraformaldehyde. After permeabilizing the cell membranes with $0.1 \%$ TritonX-100 for 3 min, non-specific binding sites were blocked by incubating with $1 \%$ BSA. Mouse monoclonal LRP-1 antibody (5A6) (Progen, Heidelberg, Germany) or control mouse IgG (Abcam, Cambridge, UK), $5 \mu \mathrm{g} / \mathrm{ml}$ in PBS 1\% BSA, were incubated with the cells for $1 \mathrm{~h}$ at RT, followed by incubation with AlexaFluor488 goat anti-mouse IgG (Invitrogen, Taastrup, Denmark). Cell nuclei were stained with a solution of 1:1000 DRAQ5 in PBS (Biostatus Ltd, Leicestershire, UK). DakoCytomation Fluorescent Medium (Dako Norge, Kjelsås, Norway) was used for mounting. Pictures were taken using a Zeiss Axiovert microscope (x63 objective) and LSM 510 software (Karl Zeiss Microimaging GmbH, Göttingen, Gemany).

\section{Ligand blotting with ${ }^{125} I-R A P$}

Total cell protein of LSECs, PCs and human glioblastoma cells (U87) (LGC Standards $\mathrm{AB}$, Borås, Sweden) were extracted with a buffer consisting of $20 \mathrm{mM}$ Hepes $\mathrm{pH}$ 7.4, $124 \mathrm{mM} \mathrm{NaCl}, 10 \mathrm{mM} \mathrm{CaCl}_{2}, 1 \%$ CHAPS, $1 \mathrm{mM}$ PMSF and protease inhibitor cocktail for $3 \mathrm{~h}$ at $4{ }^{\circ} \mathrm{C}$. The samples were diluted, divided into two, and incubated overnight at $4^{\circ} \mathrm{C}$ with Dynabeads coupled with BSA or RAP. The Dynabeads were washed and bound proteins eluted and separated by SDS-PAGE (7\% Tris-Acetate) under non-reducing conditions. Protein bands were visualized by silver staining (SilverQuest, Invitrogen, Taastrup, Denmark). The proteins were transferred to nitrocellulose filters, blocked with 
$5 \% \mathrm{BSA}$ and incubated overnight at $4{ }^{\circ} \mathrm{C}$ with ${ }^{125} \mathrm{I}$-RAP before phosphorimaging (Fuji BAS5000).

\section{Identification of LRP-1 by mass spectrometry}

A band of $>500 \mathrm{kDa}$ was excised from the silver-stained gel, reduced with DTT, alkylated with iodoacetamide and digested with trypsin [36]. Nano-LC-ESI-MSMS was performed (see supplementary materials and methods). Peak lists of MSMS spectra were generated with DTASuperCharge (http://msquant.sourceforge.net/) and searched with MASCOT against the mammalian part of the IPI_rat database.

\section{LRP mRNA levels in PCs, LSECs and KCs}

Total RNA was extracted from isolated PCs, Kupffer and LSECs using total RNA isolation kit from Macherey-Nagel (Duren, Germany). Approximately 2-10 million plated cells were lysed (PCs were in suspension). The quantity and quality of RNA was determined by Nanodrop (ThermoFisher Scientific, Wilmington, DE, USA) and by an electropheretic bioanalyzer Agilent 2100 using the Pico 6000 Assay (Agilent Technologies, Santa Clara, CA, USA). The 260/280 ratios in all samples were 2.1 and $18 \mathrm{~S} / 28 \mathrm{~S}$ ratios were between 1.1-1.4. The yields were $43,1 \mu \mathrm{g} / \mathrm{ml}, 15,8 \mu \mathrm{g} / \mathrm{ml}$ and 3647,0 $\mu \mathrm{g} / \mathrm{ml}$ for LSECs, KCs and PCs, respectively. Less than $2 \mu \mathrm{g}$ of RNA for each tell type was added to the cDNA reaction using MuLV Reverse transcriptase, random decamers, dNTP mix and placental RNAse inhibitor (Ambion, Austin,Texas, USA). RT-PCR was performed with AmpliTaq Gold, Taqman Universal PCR master mix, primer/probe kit m1 LRP1and GAPDH (all from Applied Biosystems, Foster City, CA, USA). Expression 
levels of LRP were determined by a relative comparison $\Delta \Delta \mathrm{CT}$ method where the $\Delta \mathrm{Ct}$ for GAPDH and LRP was compared for each cell type and then related to that of PCs.

\section{Statistical Analysis}

SPSS package for Windows version 15.0 (SPSS Inc., Chicago, Ill, USA) was used for statistical analyses. Two-sided $p$ values less than 0.05 were considered significant. Halflife data was analyzed using GraphPad Prism 4 (GraphPad Software, Inc. La Jolla, CA, USA). 


\section{Results}

\section{Anatomical distribution in vivo of intravenously injected ${ }^{125} I-R A P$ and ${ }^{125} I-\alpha_{2} M *$}

The anatomical distribution was investigated $10 \mathrm{~min}$ after lateral tail vein administration of ${ }^{125}$ I-RAP or ${ }^{125} \mathrm{I}-\alpha_{2} \mathrm{M}^{*}$. The blood was removed by systemic perfusion through the heart and 15 organs were surgically excised and measured for radioactivity. In accordance with previous studies, we found that the liver is the main site of uptake (Figure 1), and that only very small amounts of radioactivity were recovered in other organs (not shown).

\section{Hepatocellular distribution}

To determine which liver cells are responsible for RAP and $\alpha_{2} \mathrm{M}^{*}$ uptake, ${ }^{125} \mathrm{I}-\mathrm{RAP}$ and

${ }^{125} \mathrm{I}-\alpha_{2} \mathrm{M}^{*}$ were i.v injected into rats followed by liver perfusion with collagenase and isolation of PCs, LSECs and KCs by means of Percoll gradient and an antibody-based magnetic separation method (MACS). All steps were performed at $4{ }^{\circ} \mathrm{C}$ to prevent cellular loss of internalized ligand due to degradation. In the whole liver, $93.1 \pm 1 \%$ of RAP and $82.2 \pm 6 \% \alpha_{2} \mathrm{M}^{*}$ was found associated with the PCs (Figure 2). The LSECs and KCs were further purified using specific antibodies [11]. The ICAM-1 positive cells (LSECs) were found to be responsible for $5.3 \pm 1.3 \%$ of RAP uptake and $11.1 \pm 6.7 \%$ of $\alpha_{2} \mathrm{M}^{*}$ uptake, while the $\mathrm{CD} 11 \mathrm{~b}$ positive cells $(\mathrm{KCs})$, for $1.6 \pm 0.2 \%$ and $6.8 \pm 0.7 \%$, respectively (Figure 2).

\section{In vitro studies}


Endocytosis kinetics was studied to compare the uptake of ${ }^{125} \mathrm{I}-\mathrm{RAP}$ and ${ }^{125} \mathrm{I}-\alpha_{2} \mathrm{M}^{*}$ in cultures of PCs, LSECs and KCs. The endocytosis in PCs increased almost linearly over time, with 7.6 $\pm 1.0 \mathrm{ng}$ RAP being endocytosed and 5.7 $\pm 0.4 \mathrm{ng}$ degraded after $4 \mathrm{~h}$ of incubation (Figure 3-left panel). Degradation products were detected in the medium after approx. $20 \mathrm{~min}$, after which degradation proceeded at the same rate as cellular uptake. Similar kinetics were observed in KCs, but the total amount of endocytosed RAP at the end of the incubation time was 4 times lower than in PCs. The uptake in LSECs reached a plateau, with $1.4 \pm 0.4 \mathrm{ng}$ RAP being endocytosed, and $0.6 \pm 0.2 \mathrm{ng}$ degraded after $2 \mathrm{~h}$. The kinetics of endocytosis of ${ }^{125} \mathrm{I}-\alpha_{2} \mathrm{M}^{*}$ in PCs and LSECs were also similar, with 3 fold more uptake in PCs as compared to the uptake in LSECs (Figure 3-right panel). However, in the $\mathrm{KCs}$, it was only after $4 \mathrm{~h}$ of incubation when degradation products could be measured in the supernatant, while at shorter time points, the $\alpha_{2} \mathrm{M}^{*}$ was only found bound to the cells.

Specificity of endocytosis of the two ligands was studied in primary cultures of LSECs. Excess amounts of non-labeled RAP inhibited the endocytosis of trace amounts of ${ }^{125} \mathrm{I}$ RAP by $88.0 \pm 0.1 \%$, suggesting that the uptake of RAP is receptor mediated (Figure 4A). To gain further insights into the receptor mediated endocytosis, excess amounts of unlabelled ligands for known candidate receptors were added to primary cultures of LSECs together with ${ }^{125}$ I-RAP. So far, three major receptors for endocytosis have been identified on LSECs, i.e. the hyaluronan/scavenger receptor (Stabilin2), the mannose/collagen $\alpha$-chain receptor (MANN/COLLA-R), and the Fc $\gamma$-receptor IIb [22, $25,26,28]$. Various macromolecules known to bind to these LSECs endocytosis receptors were tested for potential inhibition of RAP uptake. The presence of high 
concentrations of formaldehyde treated serum albumin (FSA) or hyaluronan (HA) (ligands for Stabilin2), mannan or collagen $\alpha$-chains ( $\alpha$-coll) (ligands for the MANN/COLLA-R) had no effect on the endocytosis and degradation of RAP. Inhibition of the Fc $\gamma$-receptor IIb was not tested, as this receptor recognizes only the Fc domain of IgG-immune complexes [23].

Excess amounts of unlabeled $\alpha_{2} M^{*}$ inhibited the endocytosis of ${ }^{125} \mathrm{I}-\alpha_{2} M^{*}$ by $73.0 \%$ $(\mathrm{p}<0.001)$ (Figure 4B). The presence of RAP had a significant inhibitory effect on both the cell associated and degraded ${ }^{125} \mathrm{I}-\alpha_{2} \mathrm{M}^{*}$, and it inhibited the total uptake by $50.1 \%$ $(\mathrm{p}<0.001)$, suggesting the involvement of the LRP-1 in uptake.

\section{Immunofluorescence staining for LRP-1}

We used immunostaining to further investigate whether the LRP-1 receptor is expressed on LSECs. Paraformaldehyde fixed cultures of LSECs were immunostained using mouse monoclonal LRP-1 antibody recognizing the $\beta$-chain (5A6). The cells stained positively for LRP-1, as visualized by confocal microscopy using goat AlexaFluor488 anti-mouse antibody (green) (Figue 5). To determine if the LRP-1 positive cells are LSECs, the cells were preincubated with TRITC-FSA (red), a ligand that is exclusively taken up by the LSECs in the liver [13]. No staining was observed when the cells were treated with the secondary antibody only or with control mouse IgG (not shown).

\section{LRP-1 expression in liver cells}


The expression of LRP in the different liver cells was assessed by extraction of mRNA and RT-PCR. We found that after normalizing for an internal mRNA control GAPDH (which showed minimum variation in samples), the LRP-1 expression levels in PCs were 6 times higher than in LSECs and KCs, with LSECs and KCs expressing approximately similar levels. To further confirm that LRP-1 is expressed in LSECs, total cell protein was incubated with Dynabeads coupled to RAP, to pull down the receptor/s binding RAP. Bound proteins were eluted from the beads, and run in parallel on two SDS-PAGE gels under non-reducing conditions. The proteins on the first gel were visualized by silver staining (Figure 6.A). Dynabeads coupled to BSA were used as negative control showing that LRP-1 does not bind unspecifically to the beads. PCs and U87 cell line were used as positive controls, as both cell types are known to express LRP-1 [5, 34]. A band of > 500 $\mathrm{kDa}$ appeared on the silver stained gel from cell extracts of all three cell types (Figure 6.A). The proteins from the second gel were transferred to nitrocellulose filters and incubated with ${ }^{125}$ I-RAP before phosphorimaging. The results presented in Figure 6.B show that ${ }^{125}$ I-RAP bound to a single protein from the cell extracts of LSECs. The respective band corresponded to a similar band from the U87 and PCs extracts. A sensitive and specific high-performance liquid chromatography-tandem mass spectrometry using electrospray ionization (LC-ESI-MSMS) was chosen to study the band excised from the silver-stained gel. Rat LRP-1 (IPI00369995) was identified with a Mascot score of 134. Identified peptides are listed in Table 1 (supplementary material). 


\section{Discussion}

RAP, a potent inhibitor of all known ligand interactions with LRP-1, and $\alpha_{2} \mathrm{M}^{*}$, a specific ligand for the LRP-1 receptor, were used in this study to investigate whether LRP-1 is expressed in liver cells other than PCs. In agreement with previous studies we found that the liver is the principal elimination site of intravenously administered RAP and $\alpha_{2} \mathrm{M}^{*}$. Liver cell separation showed that intravenously administered ${ }^{125}$ I-RAP and ${ }^{125} \mathrm{I}-\alpha_{2} \mathrm{M}^{*}$ accumulated mainly in PCs (93\% and $82 / \%$ of liver uptake, respectively), while $5 \%$ and $11 \%$ were associated with LSECs, respectively. Endocytosis by LSECs of both ligands in vitro was receptor mediated, and succeeded by degradation. The uptake of ${ }^{125}$ I-RAP was not inhibited by ligands to known endocytosis receptors in LSECs, while uptake of ${ }^{125} \mathrm{I}-\alpha_{2} \mathrm{M}^{*}$ was significantly inhibited by excess of non-labeled RAP, suggesting the involvement of LRP-1. An immunofluorescence assay using a monoclonal LRP-1 antibody showed positive staining in LSECs. Ligand blot analyses using total cell protein and ${ }^{125}$ I-RAP followed by mass spectrometry further confirmed and identified LRP-1 in LSECs.

Several studies have shown that $\alpha_{2} \mathrm{M}$-protease complexes have a circulatory half-life of 2-4 min (for review, see[41]), and RAP has a half-life of 0.5 min [43]. Using whole body autoradiography, it has been reported that the liver was the main site for uptake of both ligands $[32,43]$. In this study we investigated the anatomical distribution by measuring the radioactivity in 15 organs, 10 min after intravenous injection. This method gives a better quantification of the distribution since the blood is washed out of the organs by systemic perfusion, and the radioactivity is measured in the total organ. Our results were 
in accordance with the previous findings, with the liver being the main site of uptake of ${ }^{125} \mathrm{I}-\mathrm{RAP}$ and ${ }^{125} \mathrm{I}-\alpha_{2} \mathrm{M}^{*}$.

It has been previously reported that the liver PCs are the main site of uptake of $\alpha_{2} \mathrm{M}^{*}[10$, 15]. The authors used autoradiography as a method for identifying the anatomical site of uptake. This technique, however, makes it difficult to distinguish between KCs and LSECs. Since at that time (1985) it was generally believed that $\mathrm{KC}=$ liver reticuloendothelial system (RES), it is fully understandable that the authors did not suggest the possibility that LSECs could be an alternative site of uptake in addition to the KCs. It was not until 1990 that LSEC was proposed, based on a solid body of evidence, to be a very important part of the liver RES [40]. In our study, we have used an antibodybased purification method that allowed us to achieve higher purities and more defined cell populations. Our results show that LSECs also contributed to the elimination of RAP and $\alpha_{2} \mathrm{M}^{*}$ from the circulation, albeit to a lesser extent than PCs.

The most likely receptor candidate, LRP-1, has previously been shown to be expressed in the liver by PCs only $[24,34]$. The following findings in the present study point to the presence and a functional role for LRP-1 in LSECs. First, excessive amounts of unlabeled RAP efficiently inhibited the uptake and degradation of ${ }^{125} \mathrm{I}-\mathrm{RAP}$ and ${ }^{125} \mathrm{I}-\alpha_{2} \mathrm{M}^{*}$ in primary cultures of LSECs. Second, excess amounts of ligands to known scavenger receptors in LSECs failed to inhibit the uptake of RAP.

To obtain direct evidence for identification of LRP-1 in LSECs and thereby rule out possible influence of marginal contamination of PCs, the cell cultures were pre-incubated 
with TRITC-FSA, a ligand that is known to be taken up only by the LSECs in the liver [12]. Immunofluorescence staining of the cells with TRITC-FSA and LRP-1 antibody revealed double staining and provided strong evidence for the expression of LRP-1 in LSECs. Further isolation of a RAP-binding protein of MW > $500 \mathrm{kDa}$ from LSEC extracts, with subsequent mass spectrometry, confirmed the expression of LRP-1 in LSEC.

Our time course studies of RAP and $\alpha_{2} \mathrm{M}^{*}$ endocytosis in LSECs and KCs revealed binding and degradation of the ligands, suggesting a functional role of LRP-1 in these cells. However, the functional capacity of LRP-1 appeared to be lower in LSECs and KCs than in PCs (Figure 3). LRP-1 mRNA expression was detected in all three liver cell types, and relative LRP-1 expression level was 6 times greater in PCs than in LSECs and KCs. If the relative protein expression levels mirror the RNA levels, this may explain the differences between RAP and $\alpha_{2} \mathrm{M}^{*}$ uptake observed in the in vitro PC and non-PC cell assays. Another interesting finding was that the uptake capacity for RAP was higher in all three cell types as compared to that for $\alpha_{2} \mathrm{M}^{*}$. This may be due to involvement of other receptor(s) that recognize RAP. Such receptor could be the LDL receptor [30] which is known to be expressed on PCs and is able to bind to RAP, although with less affinity than LRP-1 [3, 24].

In conclusion, we demonstrate for the first time that the expression of functional LRP-1 in liver is not restricted only to PCs, it is also found in LSECs, and to a lesser extent in KCs. Characterized by a very high endocytic activity [37], LSECs would contribute 
significantly to the elimination of the various LRP-1 ligands from the circulation in normal, healthy conditions.

However, in pathological conditions, such as severe fatty liver diseases, as well as in aging [14, 21, 29], significant changes occur in the hepatic sinusoids (e.g. fibrosis, narrowing of the sinusoids, reduced blood flow and capillarization of the liver sinusoids). These changes are hallmarked structurally by a progressive loss in fenestrae in LSECs, concomitant with the development of a basal lamina and deposition of collagen in the space of Disse. Given the role of fenestration in the transfer of lipoproteins from the blood to hepatocytes, it is likely that defenestration will impair lipoprotein/chylomicron remnants clearance by the hepatocytes. In addition, the transport in the opposite direction of some lipoproteins manufactured by hepatocytes will be impaired. Further studies are needed to investigate the endocytic function of LSECs via the LRP-1 in pathological conditions. 


\section{Acknowledgment}

We thank Prof. Jan Olof Winberg and laboratory engineer Eli Berg from the

Biochemistry Research Group, for their help with the trypsin activation of $\alpha_{2} \mathrm{M}$ and the zymography testing of the complex. We thank Dr. Peter McCourt for reviewing the manuscript. The authors who have taken part in this study declared that they do not have anything to disclose regarding funding from industry or conflict of interest with respect to this manuscript. 


\section{REFERENCES}

[1] Barrett AJ, Starkey PM. The interaction of alpha 2-macroglobulin with proteinases. Characteristics and specificity of the reaction, and a hypothesis concerning its molecular mechanism. Biochem J 1973;133(4): 709-724.

[2] Beisiegel U, Weber W, Ihrke G, Herz J, Stanley KK. The LDL-receptor-related protein, LRP, is an apolipoprotein E-binding protein. Nature 1989;341(6238): 162-164. [3] Brown MS, Goldstein JL. A receptor-mediated pathway for cholesterol homeostasis. Science 1986;232(4746): 34-47.

[4] $\mathrm{Bu}$ G, Geuze HJ, Strous GJ, Schwartz AL. 39 kDa receptor-associated protein is an ER resident protein and molecular chaperone for LDL receptor-related protein. Embo J 1995;14(10): 2269-2280.

[5] Bu G, Maksymovitch EA, Geuze H, Schwartz AL. Subcellular localization and endocytic function of low density lipoprotein receptor-related protein in human glioblastoma cells. J Biol Chem 1994;269(47): 29874-29882.

[6] Bu G, Maksymovitch EA, Schwartz AL. Receptor-mediated endocytosis of tissue-type plasminogen activator by low density lipoprotein receptor-related protein on human hepatoma HepG2 cells. J Biol Chem 1993;268(17): 13002-13009.

[7] Bu G, Williams S, Strickland DK, Schwartz AL. Low density lipoprotein receptor-related protein/alpha 2-macroglobulin receptor is an hepatic receptor for tissuetype plasminogen activator. Proc Natl Acad Sci U S A 1992;89(16): 7427-7431.

[8] Christensen JH, Hansen PK, Lillelund O, Thogersen HC. Sequence-specific binding of the $\mathrm{N}$-terminal three-finger fragment of Xenopus transcription factor IIIA to the internal control region of a 5S RNA gene. FEBS Lett 1991;281(1-2): 181-184. [9] Damiao AO, Sipahi AM, Albuquerque MR, Laudanna AA, Quintao EC. Chylomicron metabolism in experimental cirrhosis and cholestasis. Res Exp Med (Berl) 1993;193(2): 89-95.

[10] Davidsen O, Christensen EI, Gliemann J. The plasma clearance of human alpha 2macroglobulin-trypsin complex in the rat is mainly accounted for by uptake into hepatocytes. Biochim Biophys Acta 1985;846(1): 85-92.

[11] Do H, Healey JF, Waller EK, Lollar P. Expression of factor VIII by murine liver sinusoidal endothelial cells. J Biol Chem 1999;274(28): 19587-19592.

[12] Elvevold K, Simon-Santamaria J, Hasvold H, McCourt P, Smedsrod B, Sorensen

KK. Liver sinusoidal endothelial cells depend on mannose receptor-mediated recruitment of lysosomal enzymes for normal degradation capacity. Hepatology 2008;48(6): 20072015.

[13] Elvevold KH, Nedredal GI, Revhaug A, Smedsrod B. Scavenger properties of cultivated pig liver endothelial cells. Comp Hepatol 2004;3(1): 4.

[14] Farrell GC, Teoh NC, McCuskey RS. Hepatic microcirculation in fatty liver disease. Anat Rec (Hoboken) 2008;291(6): 684-692.

[15] Feldman SR, Rosenberg MR, Ney KA, Michalopoulos G, Pizzo SV. Binding of alpha 2-macroglobulin to hepatocytes: mechanism of in vivo clearance. Biochem Biophys Res Commun 1985;128(2): 795-802.

[16] Gliemann J, Larsen TR, Sottrup-Jensen L. Cell association and degradation of alpha 2-macroglobulin-trypsin complexes in hepatocytes and adipocytes. Biochim Biophys Acta 1983;756(2): 230-237. 
[17] Hansen B, Longati P, Elvevold K, Nedredal GI, Schledzewski K, Olsen R, et al. Stabilin-1 and stabilin-2 are both directed into the early endocytic pathway in hepatic sinusoidal endothelium via interactions with clathrin/AP-2, independent of ligand binding. Exp Cell Res 2005;303(1): 160-173.

[18] Herz J, Kowal RC, Goldstein JL, Brown MS. Proteolytic processing of the $600 \mathrm{kd}$ low density lipoprotein receptor-related protein (LRP) occurs in a trans-Golgi compartment. Embo J 1990;9(6): 1769-1776.

[19] Herz J, Strickland DK. LRP: a multifunctional scavenger and signaling receptor. J Clin Invest 2001;108(6): 779-784.

[20] Ho AS, Cheng CC, Lee SC, Liu ML, Lee JY, Wang WM, et al. Novel biomarkers predict liver fibrosis in hepatitis $C$ patients: alpha 2 macroglobulin, vitamin D binding protein and apolipoprotein AI. J Biomed Sci 2010;17: 58.

[21] Ito Y, Sorensen KK, Bethea NW, Svistounov D, McCuskey MK, Smedsrod BH, et al. Age-related changes in the hepatic microcirculation in mice. Exp Gerontol 2007;42(8): 789-797.

[22] Lovdal T, Andersen E, Brech A, Berg T. Fc receptor mediated endocytosis of small soluble immunoglobulin $\mathrm{G}$ immune complexes in Kupffer and endothelial cells from rat liver. J Cell Sci 2000;113 ( Pt 18): 3255-3266.

[23] Lovdal T, Berg T. Transcription of $\mathrm{Fc}$ (gamma) receptors in different rat liver cells. Cell Biol Int 2001;25(8): 821-824.

[24] Lund H, Takahashi K, Hamilton RL, Havel RJ. Lipoprotein binding and endosomal itinerary of the low density lipoprotein receptor-related protein in rat liver. Proc Natl Acad Sci U S A 1989;86(23): 9318-9322.

[25] Magnusson S, Berg T. Extremely rapid endocytosis mediated by the mannose receptor of sinusoidal endothelial rat liver cells. Biochem J 1989;257(3): 651-656.

[26] Malovic I, Sorensen KK, Elvevold KH, Nedredal GI, Paulsen S, Erofeev AV, et al. The mannose receptor on murine liver sinusoidal endothelial cells is the main denatured collagen clearance receptor. Hepatology 2007;45(6): 1454-1461.

[27] Markwell MA. A new solid-state reagent to iodinate proteins. I. Conditions for the efficient labeling of antiserum. Anal Biochem 1982;125(2): 427-432.

[28] McCourt PA, Smedsrod BH, Melkko J, Johansson S. Characterization of a hyaluronan receptor on rat sinusoidal liver endothelial cells and its functional relationship to scavenger receptors. Hepatology 1999;30(5): 1276-1286.

[29] McLean AJ, Cogger VC, Chong GC, Warren A, Markus AM, Dahlstrom JE, et al. Age-related pseudocapillarization of the human liver. J Pathol 2003;200(1): 112-117.

[30] Medh JD, Fry GL, Bowen SL, Pladet MW, Strickland DK, Chappell DA. The 39$\mathrm{kDa}$ receptor-associated protein modulates lipoprotein catabolism by binding to LDL receptors. J Biol Chem 1995;270(2): 536-540.

[31] Mego JL, Bertini F, McQueen JD. The use of formaldehyde-treated 131-Ialbumin in the study of digestive vacuoles and some properties of these particles from mouse liver. J Cell Biol 1967;32(3): 699-707.

[32] Ohlsson K. Elimination of 125-I-trypsin alpha-macroglobulin complexes from blood by reticuloendothelial cells in dogs. Acta Physiol Scand 1971;81(2): 269-272. [33] Pertoft H, Smedsrod B. Separation and characterization of liver cells. In: Pretlow TG, Pretlow TPNY, eds Cell Separation Methods and Selected Applications Volume 4 Academic Press 1987: 1-24. 
[34] Schmoelzl S, Benn SJ, Laithwaite JE, Greenwood SJ, Marshall WS, Munday NA, et al. Expression of hepatocyte low-density lipoprotein receptor-related protein is posttranscriptionally regulated by extracellular matrix. Lab Invest 1998;78(11): 1405-1413. [35] Seternes T, Sorensen K, Smedsrod B. Scavenger endothelial cells of vertebrates: a nonperipheral leukocyte system for high-capacity elimination of waste macromolecules. Proc Natl Acad Sci U S A 2002;99(11): 7594-7597.

[36] Shevchenko A, Wilm M, Vorm O, Mann M. Mass spectrometric sequencing of proteins silver-stained polyacrylamide gels. Anal Chem 1996;68(5): 850-858.

[37] Smedsrod B. Clearance function of scavenger endothelial cells. Comp Hepatol 2004;3 Suppl 1: S22.

[38] Smedsrod B, Johansson S, Pertoft H. Studies in vivo and in vitro on the uptake and degradation of soluble collagen alpha 1(I) chains in rat liver endothelial and Kupffer cells. Biochem J 1985;228(2): 415-424.

[39] Smedsrod B, Pertoft H. Preparation of pure hepatocytes and reticuloendothelial cells in high yield from a single rat liver by means of Percoll centrifugation and selective adherence. J Leukoc Biol 1985;38(2): 213-230.

[40] Smedsrod B, Pertoft H, Gustafson S, Laurent TC. Scavenger functions of the liver endothelial cell. Biochem J 1990;266(2): 313-327.

[41] Sottrup-Jensen L. Alpha-macroglobulins: structure, shape, and mechanism of proteinase complex formation. J Biol Chem 1989;264(20): 11539-11542.

[42] Tamaki C, Ohtsuki S, Iwatsubo T, Hashimoto T, Yamada K, Yabuki C, et al.

Major involvement of low-density lipoprotein receptor-related protein 1 in the clearance of plasma free amyloid beta-peptide by the liver. Pharm Res 2006;23(7): 1407-1416.

[43] Warshawsky I, Bu G, Schwartz AL. 39-kD protein inhibits tissue-type plasminogen activator clearance in vivo. J Clin Invest 1993;92(2): 937-944.

[44] Waynforth HB, Flecknell PA. Experimental and Surgical Technique in the Rat. San Diego, CA; Academic; 1992(Second Edition): 342.

[45] Willnow TE. The low-density lipoprotein receptor gene family: multiple roles in lipid metabolism. J Mol Med 1999;77(3): 306-315.

[46] Willnow TE. Receptor-associated protein (RAP): a specialized chaperone for endocytic receptors. Biol Chem 1998;379(8-9): 1025-1031.

[47] Wisse E. An electron microscopic study of the fenestrated endothelial lining of rat liver sinusoids. J Ultrastruct Res 1970;31(1): 125-150. 


\section{FIGURE LEGENDS}

Fig. 1. Anatomical distribution

${ }^{125} \mathrm{I}-\mathrm{RAP}$ (white bars) or ${ }^{125} \mathrm{I}-\alpha_{2} \mathrm{M} *(0.5 \mu \mathrm{g})$ (gray bars) in $0.5 \mathrm{ml}$ physiological saline were i.v. injected in the tail vein, and radioactivity in 15 organs free of blood was measured 10 min after injection. The results are presented in radioactivity - counts per minute (cpm) recovered within each organ. Radioactivity in tissues and organs other than those shown in the figure was less than $10^{4} \mathrm{cpm}$. Bars are means \pm SD for 3 animals.

Fig. 2. Hepatocellular distribution

Ten min after i.v. injection of $5 \mu \mathrm{g}{ }^{125} \mathrm{I}-\mathrm{RAP}$ (white bars) or ${ }^{125} \mathrm{I}-\alpha_{2} \mathrm{M}^{*}$ (gray bars), the liver cells were isolated by collagenase perfusion, Percoll gradient and MACS using specific antibodies for LSECs and KCs. The content of radioactivity is presented as percent per total cell population in liver, given that the total number of KCs, LSECs and PCs in rat liver relate to each other as 1:2.5:7.7 (20). Bars are means \pm SD of 3 animals.

Fig. 3. Kinetics of endocytosis of ${ }^{125} \mathrm{I}-\mathrm{RAP}$ (left panel) and ${ }^{125} \mathrm{I}-\alpha_{2} \mathrm{M}^{*}$ (right panel) in primary cultures of PCs, LSECs and KCs

Trace amounts of radio-labeled ligands (approx. $4.27 \mathrm{ng}{ }^{125} \mathrm{I}-\mathrm{RAP}$ and $10 \mathrm{ng}{ }^{125} \mathrm{I}-\alpha_{2} \mathrm{M}^{*}$ ) were added to cultures of $0.25 \times 10^{6} \mathrm{PCs}, 0.5 \times 10^{6} \mathrm{LSECs}$ and $0.3 \times 10^{6} \mathrm{KCs}$. Cellassociated $(\nabla)$ and degraded (acid-soluble) ( $\square$ ) ligands were determined after various periods of incubation at $37^{\circ} \mathrm{C}$ as described in the Materials and Methods. Total endocytosed ligand $(\circ)$ represents the sum of cell-associated and acid-soluble radioactivity. The amount of the non-specific binding and free ${ }^{125} \mathrm{I}$ in the cell free wells 
was subtracted. The results are presented as ng ligand $/ 10^{6}$ cells. Bars are means $\pm \mathrm{SD}$ of 3 experiments.

Fig. 4. Specificity of endocytosis of ${ }^{125} \mathrm{I}-\mathrm{RAP}(\mathrm{A})$ and ${ }^{125} \mathrm{I}-\alpha_{2} \mathrm{M}^{*}$ (B) in LSECs Monolayer cultures were incubated for $2 \mathrm{~h}$ at $37^{\circ} \mathrm{C}$ with approx. $4.27 \mathrm{ng}{ }^{125} \mathrm{I}-\mathrm{RAP}$ or 10 ng ${ }^{125} \mathrm{I}-\alpha_{2} \mathrm{M}^{*}$ alone (Control) or together with $100 \mu \mathrm{g} / \mathrm{ml}$ of unlabelled RAP, FSA, Mannan, $\alpha$-coll or HA. Results are presented as percentage of Control. Gray bars represent cell-associated ligand (SDS soluble). White bars represent degraded ligand (TCA soluble). Control values were $19 \pm 2 \%$ and $5 \pm 0.2 \%$ of total added ${ }^{125}$ I-RAP and ${ }^{125} \mathrm{I}-\alpha_{2} \mathrm{M}^{*}$, respectively. Bars are means \pm SEM for 3 to 7 experiments.

Fig. 5. Immunofluorescence staining for LRP-1

LSECs on fibronectin coated glass coverslips were incubated for $1 \mathrm{~h}$ at $37^{\circ} \mathrm{C}$ with TRITC-FSA (red), fixed with 4\% paraformaldehyde and cell membranes permeabilized with $0.1 \%$ Triton $\mathrm{X}-100$. Indirect immunostaining was performed using mouse monoclonal anti-LRP-1 and AlexaFluor 488 goat anti-mouse IgG (green). Cell nuclei were stained with DRAQ5 (blue).

Fig. 6. Ligand blotting Total cell proteins of LSECs, PCs and human glioblastoma cell line (U87), were incubated with Dynabeads coupled with RAP or BSA overnight. The Dynabeads were washed and RAP-binding proteins separated by SDS-PAGE (7\% Tris-Acetate), under non-reducing conditions. A band of > $500 \mathrm{kDa}$ appeared on the silver stained gel from 
cell extracts of all three cell types (A). Lane designation at top of the gel indicates the cellular source of samples that were loaded. Prestained molecular mass markers is indicated in $\mathrm{kDa}$. The proteins were transferred to nitrocellulose filters, blocked with BSA, the blot incubated with ${ }^{125}$ I-RAP and subjected to autoradiography (B). 


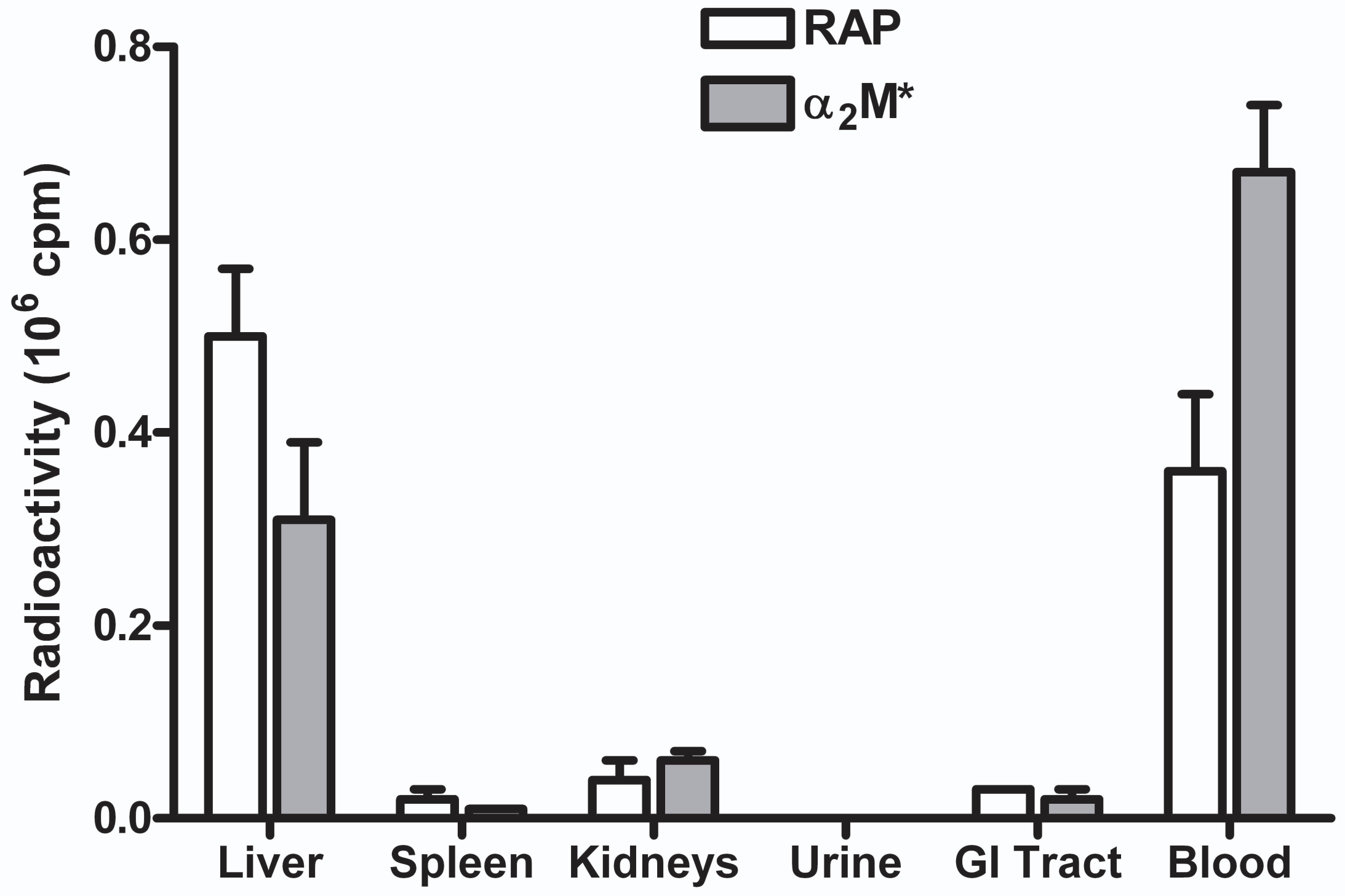


Figure 2

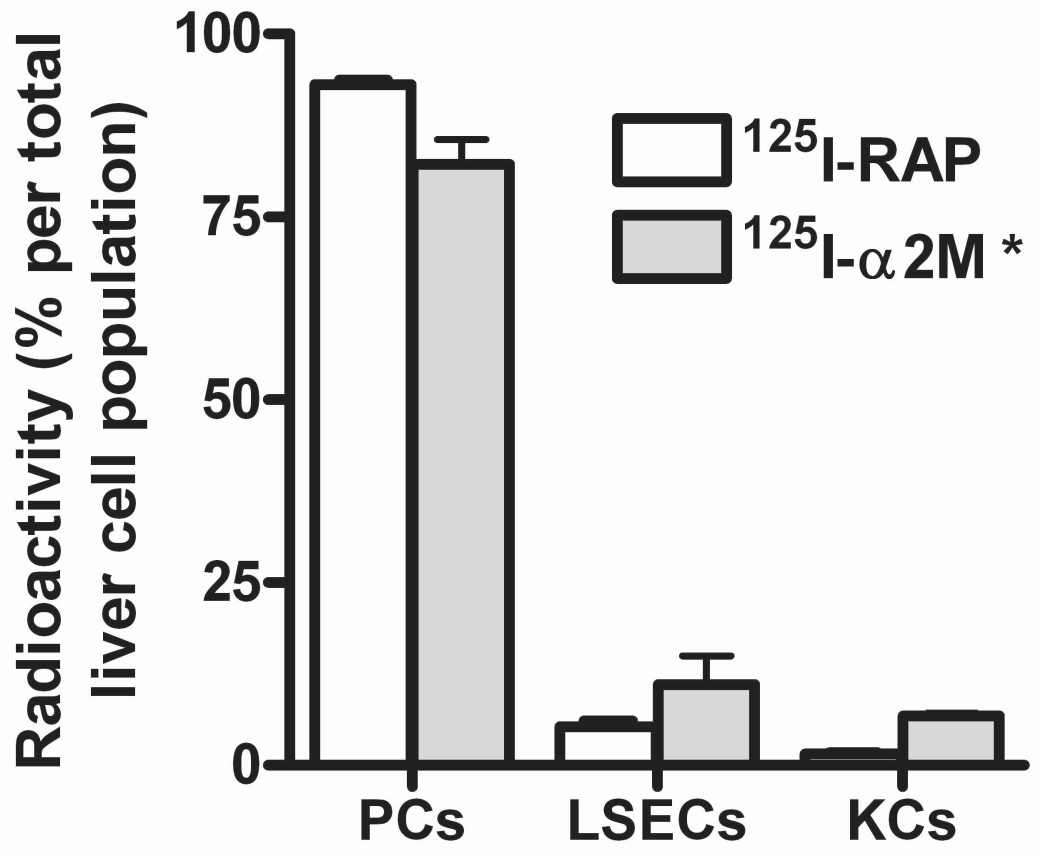


Figure 3
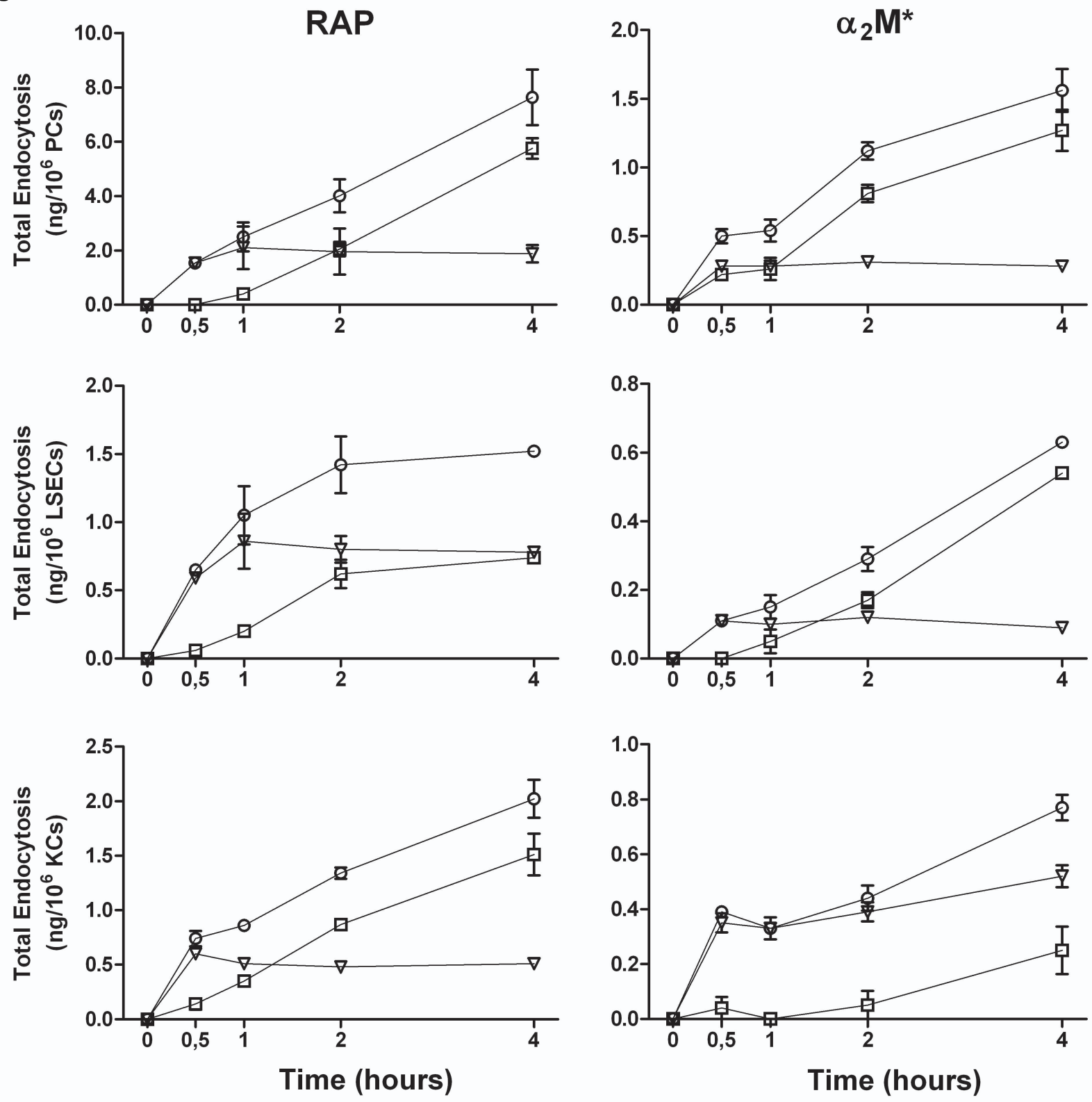

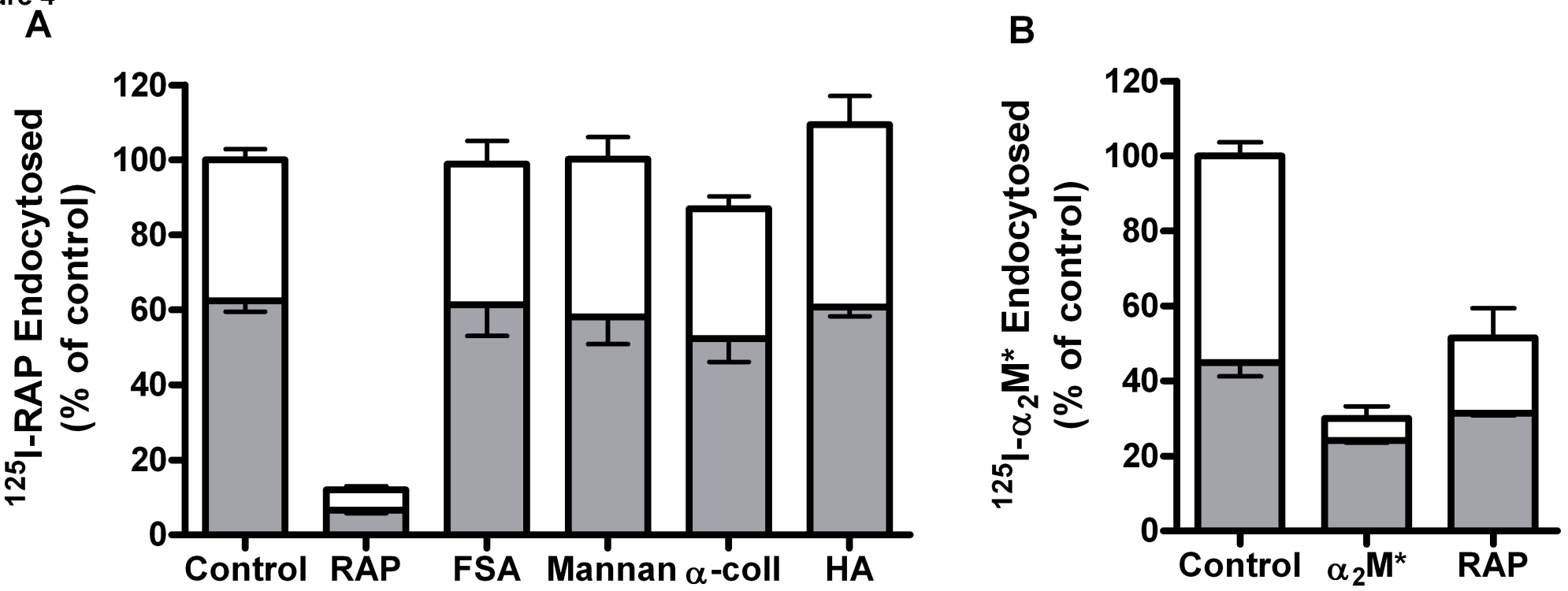

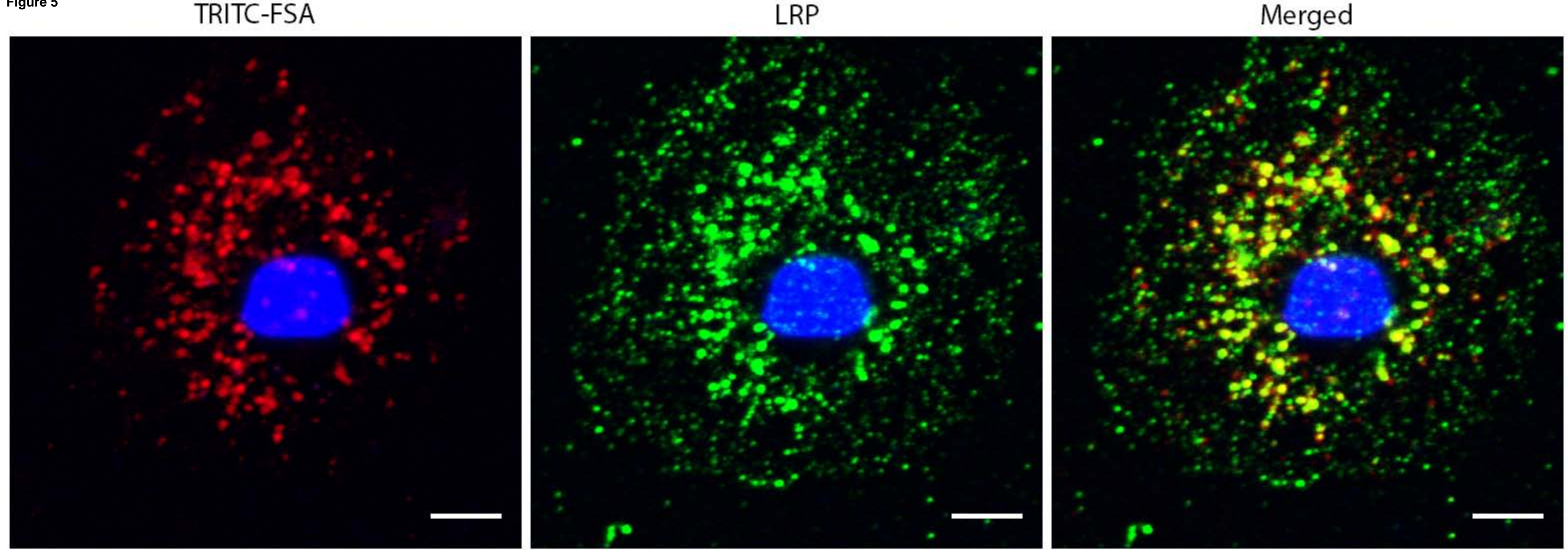

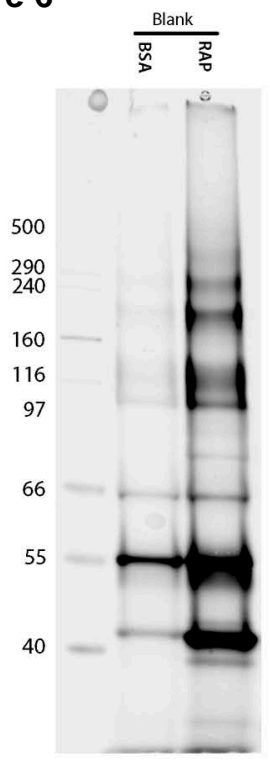

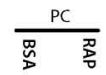

$\frac{\text { U87 }}{\text { 罟 㞼 }}$
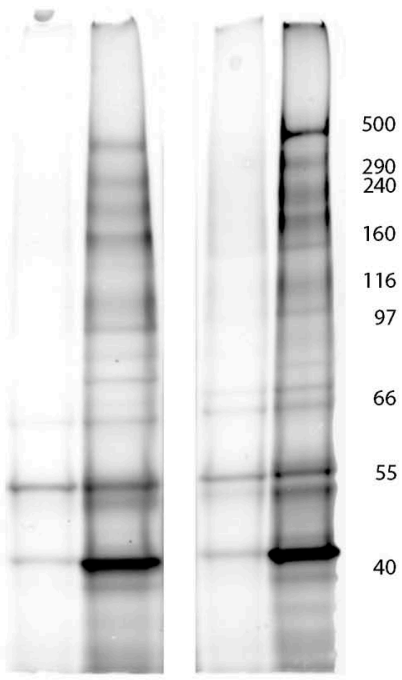

$\frac{\text { U87 }}{\stackrel{\text { P }}{>} \quad \frac{7}{D}}$

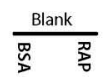

$\frac{\text { LSEC }}{\stackrel{\text { D }}{>} \quad \text { 㞧 }}$

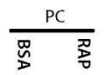



Supplementary material - RAP purification
Click here to download Supplementary material: Supplementary - RAP purification.doc Click here to download Supplementary material: Supplementary - RAP purification.doc C 


\section{Click here to download Supplementary material: Supplementary - Mass spectrometry.doc}


Supplementary material - Identified peptides MS
Click here to download Supplementary material: Supplementary - Table 1.doc

Supplementary material - Identified peptides MS
Click here to download Supplementary material: Supplementary - Table 1.doc

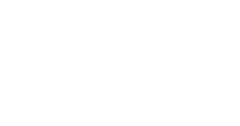

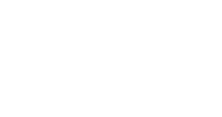
$\sqrt{3}$ (n) (1) (1)

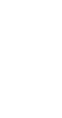
(a)

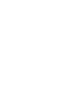

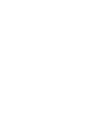

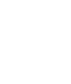

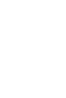

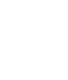

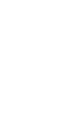
(1)

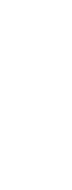

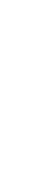

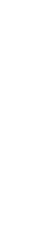
. . 列

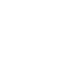

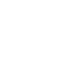

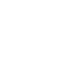

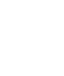

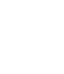
(1)

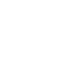
(1) 